\title{
KONSUMSI JUS JAMBU BIJI MERAH DAN PENYEMBUHAN LUKA PERINEUM
}

\author{
Didien Ika Setyarini \\ Poltekkes Kemenkes Malang, Jl.Besar Ijen No. 77 C Malang \\ Email: didienikasetyarini@yahoo.com
}

\section{The Effect of Guava Juice Consumption on Perineal Wound Healing}

\begin{abstract}
The purpose of this research is to know the effect of guava juice consumption on perineal wound healing. Experimental method with post-test only control group design method. The subject in this research is postpartum mothers with perineum rupture grade I and II. The sample in this research is 20 and the sampling technique use accidental sampling. The result research show $40 \%$ respondents who consume guava juice healed in faster time, less than seven days, meanwhile $90 \%$ respondent who didn't consume guava juice healed in norma time 7-10 days. The analysis result got that $Z_{\text {hitung }}>Z_{\text {tabel }}(-$ $2,300>-1,96) \mathrm{HO}$ rejected, So it can be conclude that consuming guava juice significantly give effect to perineal healing.
\end{abstract}

Keywords: guava juice, wound healing, postpartum

\begin{abstract}
Abstrak: Tujuan dari penelitian ini untuk mengetahui pengaruh konsumsi jus jambu biji merah terhadap penyembuhan luka perineum. Metode eksperimen dengan pendekatan post-test only control group design. Subjek penelitian ini adalah ibu postpartum dengan robekan perineum derajad I dan II. Sampel berjumlah 20 orang dengan teknik sampling accidental sampling. Data yang diperoleh dari hasil penelitian menunjukkan $40 \%$ responden yang mengkonsumsi jus jambu biji merah sembuh dalam waktu yang lebih cepat $<7$ hari, sedangkan 90\% responden yang tidak mengkonsumsi jus jambu biji merah sembuh dalam waktu normal 7-10 hari, hasil analisa data diperoleh Z hitung > Z tabel (-2,300 >-,196) HO ditolak, sehingga disimpulkan konsumsi jus jambu biji merah berpengaruh signifikansi terhadap penyembuhan luka perineum.
\end{abstract}

Kata Kunci: jus jambu, penyembuhan luka, pasca bersalin

\section{PENDAHULUAN}

Berdasarkan SDKI 2012, rata-rata angka kematian ibu (AKI) tercatat mencapai 359 per 100 ribu kelahiran hidup. Rata-rata kematian ini lebih tinggi dibanding hasil SDKI 2007 yang mencapai 228 per 100 ribu. Tiga penyebab utama Angka Kematian Ibu di Indonesia dalam bidang obstetri adalah perdarahan (45\%), infeksi (15\%) dan pre-eklampsia (13\%) (DepKes RI, 2007). Menurut data kesehatan Propinsi Jawa Timur terakhir pada tahun 2009 Angka Kematian Ibu sebesar 260 per 100.000 kelahiran hidup dan tiga penyebab Angka Kematian Ibu di Propinsi Jawa Timur yaitu perdarahan $(34,62 \%)$, pre eklampsia $(14,01 \%)$ dan infeksi (3,02\%) (DinKes Jatim, 2009).
Masa nifas merupakan masa kritis baik ibu maupun bayinya dan diperkirakan $50 \%$ kematian terjadi dalam 24 jam pertama setelah persalinan. Adapun salah satu komplikasi yang sering terjadi pada masa nifas adalah ruptur perineum yang terjadi pada hampir semua persalinan pertama dan tidak jarang pada persalinan berikutnya, yang dapat menyebabkan perdarahan dan infeksi sehingga mengakibatkan tingginya morbiditas dan mortalitas ibu (Prawirohardjo, 2005)

Ruptur perineum adalah salah satu masalah dalam persalinan yang dapat menimbulkan komplikasi perdarahan dan infeksi, ruptur perineum dapat menjadi hebat khususnya pada ruptur derajat dua dan tiga atau jika ruptur meluas ke samping atau naik ke vulva mengenai clitoris. 
Laserasi perineum dapat dengan mudah terkontaminasi feses karena dekat dengan anus. Infeksi juga dapat menjadi sebab luka tidak segera menyatu sehingga timbul jaringan parut. Perineum adalah otot, kulit, dan jaringan yang ada diantara kelamin dan anus. Trauma perineum adalah luka pada perineum sering terjadi saat proses persalinan. Hal ini karena desakan kepala atau bagian tubuh janin secara tiba-tiba, sehingga kulit dan jaringan perineum robek. Trauma perineum lebih sering terjadi pada keadaankeadaan seperti ukuran janin terlalu besar, proses persalinan yang lama, penggunaan alat bantu persalinan (Prawiroharjo, 2006), berat badan bayi (Destiati\&Prabandari, 2011), paritas (Pratami \&Kuswanti, 2015), dan posisi mengejan (Asiyah, 2013).

Penyembuhan luka perineum dipengaruhi oleh beberapa faktor, salah satunya adalah faktor nutrisi, yang paling penting untuk penyembuhan luka adalah protein dan vitamin $\mathrm{C}$, protein dan vitamin $\mathrm{C}$ sangat penting peranannya dalam proses penyembuhan luka, protein adalah dasar untuk membentuk kulit baru dan memperbaiki sel yang rusak. vitamin $C$ punya peranan untuk mencegah infeksi dan perdarahan pada luka,Vitamin C juga memiliki peran penting dalam sintesis kolagen, dalam pembentukan ikatan antara helai serat kolagen, membantu memberikan kekuatan ekstra dan stabilitas. Ada banyak bukti yang menunjukkan meningkatnya kebutuhan untuk vitamin $C$ selama cedera, stres dan sepsis, tetapi tidak ada bukti bahwa dosis meningkatkan hasil klinis (Gray dan Cooper 2001). Kolagen sangat penting karena merupakan dasar protein yang membentuk semua jaringan dan organ. Bila terkondensasi, akan membentuk ligamentum dan tendo. Untuk mencapai penyembuhan yang optimal diperlukan keseimbangan antara kolagen yang diproduksi dengan yang dipecahkan. Kolagen yang berlebihan akan terjadi penebalan jaringan parut atau hypertrophic scar, sebaliknya produksi yang berkurang akan menurunkan kekuatan jaringan parut dan luka akan selalu terbuka (Smeltzer, 2002)

Di dalam masyarakat buah jambu biji merah dikenal sebagai antioksidan karena mengandung banyak vitamin $\mathrm{C}$. Vitamin $\mathrm{C}$ selain sebagai antioksidan juga sebagai penghasil kolagen, Manfaat dari kolagen bekerja dengan elastin untuk mendukung jaringan tubuh, membantu kulit dengan kelenturan dan kekuatan yang sering disebut sebagai elastisitas. Studi ilmiah menunjukkan bahwa konsumsi rutin buahbuahan yang kaya vitamin $\mathrm{C}$ akan membantu tubuh meningkatkan kekebalan terhadap agen infeksi, Vitamin Csangat penting untuk kesehatan sistem imun dan untuk penyembuhan luka yang efisien. Buah Jambu biji saat menjelang matang kandungan vitamin $\mathrm{C}$ dapat mencapai 3-6 kali lipat lebih tinggi dari jeruk, jambu biji juga kaya dengan serat yang larut dalam air, terutama dibagian kulitnya sehingga dapat mengganggu penyerapan glukosa dan lemak yang berasal dari makanan dan membuangnya keluar tubuh. Penggunaan vitamin Cuntuk penyembuhan luka yaitu dosis RDA untuk wanita $60 \mathrm{mg}$ sehari (Mahsudi, 2004). Jambu Matang segar sangat baik jika dikonsumsi bersama dengan kulitnya. Buah jambu segar sebanyak 100 gram mengandung $228 \mathrm{mg}$ vitamin $\mathrm{C}$, lebih dari tiga kali DRI (asupan harian yang disarankan) (Almatsier, 2009)

Kadar vitamin $\mathrm{C}$ dalam tubuh dapat mencapai hingga $1500 \mathrm{mg}$ bila dikonsumsi 100 $\mathrm{mg} /$ hari. Jumlah ini dapat mencegah terjadi scorbut selama 3 bulan. Tanda-tanda scorbut akan terjadi bila persediaan tinggal 300mg. pada konsumsi melebihi 100 mg sehari, kelebihan akan dikeluarkan sebagai asam askorbat atau sebagai karbondioksida dalam pernapasan. Walaupun tubuh mengandung sedikit vitamin C, sebagian akan tetap dikeluarkan (Almatsier, 
2009). Dari hasil studi literatur yang dilakukan oleh peneliti diketahui bahwa vitamin $\mathrm{C}$ berperan aktif untuk mempercepat proses penyembuhan luka, dan buah yang mengandung banyak vitamin $\mathrm{C}$ salah satunya adalah jambu biji merah.

Tujuan dari penelitian ini adalah mengetahui pengaruh konsumsi jus jambu biji merah terhadap penyembuhan luka perineum.

\section{METODE PENELITIAN}

Penelitian ini menggunakan metode eksperimen dengan pendekatan post-test only control group design yaitu pengelompokan anggota sampel pada kelompok eksperimen dan kelompok kontrol dimana kelompok subyek perlakuan diobservasi percepatan penyembuhan luka perineum pada ibu postpartum setelah dilakukan intervensi pemberian jus jambu biji merah sedangkan kelompok kontrol yang tidak dilakukan intervensi diobservasi percepatan penyembuhan luka perineum.

Dalam observasi ini peneliti di dampingi dengan asisten bidan, konsumsi jus jambu biji merah dalam penelitian ini diberikan selama 10 hari dan dilakukan observasi untuk melihat kondisi luka mulai hari ke-3 sampai dengan luka kering, selanjutnya pada hari ke-7 responden diminta untuk kontrol ke bidan untuk diperiksa bagaimana keadaan lukanya.

Populasi penelitian ini adalah semua ibu postpartum hari ke-1 sebanyak 24 orang. Merujuk pada kriteria inklusi yang telah ditetapkan, maka dari 24 orang, terpilih 20 orang sebagai responden menggunakan teknik sampling non probability sampling dengan jenis accidental sampling. Dari 20 responden, 10 responden sebagai kelompok perlakuan dan 10 responden menjadi kelompok kontrol.

Metode analisis yang digunakan yaitu uji Mann-Whitney U-Test sebagai penguji hipotesis. Komparasi Mann-whitney U-test digunakan untuk menguji signifikansi hipotesis komparasi dua sampel independen dengan data berbentuk ordinal.

\section{HASIL PENELITIAN}

Responden pada penelitian ini berjumlah 20 ibu post partum, 4 diantaranya berusia $<20$ tahun dan 16 orang berusia 20-35 tahun. Latar belakang pendidikan dari responden antara lain 2 orang berlatar belakang pendidikan perguruan tinggi, 12 orang mempunyai latar belakang pendidikan SMU dan 6 orang dengan latar belakang pendidikan SMP.

Gambaran keadaan sosial ekonomi dari responden adalah dari $20 \mathrm{ibu}$ post partum yang menjadi responden, 3 diantaranya bekerja sebagai pegawai swasta, 1 orang berprofesi guru, 1 orang buruh tani dan 1 orang sebagai karyawan pabrik. Selebihnya 14 responden tidak bekerja.

Berdasarkan tabel 1, sebanya $60 \%$ responden yang mengkonsumsi jus jambu biji merah sembuh dalam waktu $7-10$ hari dan $40 \%$

Tabel 1. Penyembuhan Luka Perineum

\begin{tabular}{lcccc}
\hline \multirow{2}{*}{$\begin{array}{c}\text { Waktu Penyembuhan } \\
\text { Luka }\end{array}$} & \multicolumn{4}{c}{ Konsumsi Jus Jambu Biji Merah } \\
\cline { 2 - 5 } & \multicolumn{2}{c}{ Konsumsi } & Tidak konsumsi \\
\cline { 2 - 5 } & $\mathbf{f}$ & $\%$ & $\mathbf{f}$ & $\%$ \\
\hline Cepat (< 7 hari) & 4 & 40 & 0 & 0 \\
Normal (7-10 hari) & 6 & 60 & 9 & 90 \\
Lama ( > 10 hari) & 0 & 0 & 1 & 10 \\
\hline Total & 10 & 100 & 10 & 100 \\
\hline
\end{tabular}


mengalami penyembuhan yang lebih cepat yaitu kurang dari 7 hari. Sedangkan untuk responden yang tidak mengkonsumsi jus jambu biji merah sebagian besar (90\%) sembuh dalam waktu 710 hari dan tidak ada yang mengalami penyembuhan lebih cepat.

Setelah dilakukan analisis dengan uji statistik menggunakan taraf kesalahan $(\mathrm{p})=0,021$ $(\mathrm{p}<0,05)$, didapatkan harga $Z_{\text {tabel }}=-1,96$ Nilai $\mathrm{Z}$ yang didapatkan menunjukkan angka $-2,300$ dimana nilai $\mathrm{Z}_{\text {hitung }}$ lebih besar daripada $\mathrm{Z}_{\text {tabel }}$ $(-2,300>-1,96)$ maka $\mathrm{H} 0$ ditolak yang berarti bahwa konsumsi jus jambu biji merah berpengaruh signifikans dalam penyembuhan luka perineum.

\section{PEMBAHASAN}

Proses penyembuhan luka terjadi mula-mula darah membeku dan menghasilkan getah yang bersih serta efisien, zat-zat kimia yang lepas menarik sel-sel darah putih ke dalam daerah luka yang mati dan setiap benda asing. Pembuluhpembuluh kapiler yang baru terangsang untuk tumbuh dari pembuluh darah sekitar luka dan menghasilkan bekuan yang dicerna oleh sel-sel darah putih. Bersama dengan pembuluh kapiler yang baru, terdapat sel-sel yang disebut fibroblast. Sel-sel ini membentuk jaringan fibrosis yang kemudian menjadi jaringan parut. Pada tahap ini campuran sel dan pembuluh kapiler yang baru itu berwarna merah terang dan disebut jaringan granulasi. Ketika jaringan granulasi mencapai permukaan sel-sel epitel pada pinggir luka tumbuh menyilang dengan demikian menutupi jaringan ringan. Luka yang baru sembuh pada mulanya berwarna merah, tetapi jaringan fibroblast kemudian berkontraksi sehingga menghancurkan kapiler-kapiler yang sudah tidak diperlukan lagi (Smeltzer, 2001) Kolagen terbentuk dalam reticulum endoplasma fibroblast yang kasar. Selama proses ini, asam askorbat dibutuhkan untuk menghidroksilasi prolin menjadi hidroksipolin. Jadi pada kekurangan asam askorbat (scurvy) pembentukan kolagen sangat berkurang dan penyembuhan luka benar-benar buruk. Sintesa kolagen yang telah dimulai sejak fase proliferasi akan dilanjutkan pada fase maturasi. Kecuali pembentukan kolagen juga akan terjadi pemecahan kolagen oleh enzim kolagenase. Kolagen muda (gelatinous collagen) yang terbentuk pada fase proliferasi akan berubah menjadi kolagen yang lebih matang, yaitu lebih kuat dan struktur yang lebih baik (proses re-modelling).Untuk mencapai penyembuhan yang optimal diperlukan keseimbangan antara kolagen yang diproduksi dengan yang dipecahkan. Kolagen yang berlebihan akan terjadi penebalan jaringan parut atau hypertrophic scar, sebaliknya produksi yang berkurang akan menurunkan kekuatan jaringan parut dan luka akan selalu terbuka (Baxter, 1990)

Luka dikatakan sembuh jika terjadi kontinuitas lapisan kulit dan kekuatan jaringan kulit mampu atau tidak mengganggu untuk melakukan aktivitas yang normal. Meskipun proses penyembuhan luka sama bagi setiap penderita, namun outcome atau hasil yang dicapai sangat tergantung dari kondisi biologik masingmasing individu, lokasi serta luasnya luka. Penderita muda dan sehat akan mencapai proses yang cepat dibandingkan dengan penderita kurang gizi yang disertai dengan penyakit sistemik (diabetes melitus) (Baxter, 1990)

Hasil penelitian ini terdapat $40 \%$ responden pada kelompok perlakuan sembuh lebih cepat < 7 hari, dan sebanyak $60 \%$ responden sembuh dalam waktu yang normal yaitu antara hari ke-7 sampai hari ke-10, responden yang mengalami ruptur perineum derajat I sebanyak 5 orang, 4 responden mengalami penyembuhan luka lebih cepat yaitu $<7$ hari, dan terdapat 5 responden yang mengalami ruptur perineum derajat II, sembuh normal pada hari ke 7-10. Dari hasil penelitian menunjukkan bahwa derajat ruptur juga mempengaruhi proses penyembuhan luka 
perineum. Data tersebut menunjukkan bahwa dengan konsumsi jus jambu biji merah dapat mempengaruhi penyembuhan luka perineum karena luka lebih cepat sembuh dalam waktu < 7 hari.

Kelebihan Jambu Biji Merah karena mengandung vitamin $C$ yaitu dua kali lipat jeruk manis yang hanya $49 \mathrm{mg} / 100 \mathrm{~g}$ buah. Fungsi vitamin $\mathrm{C}$ banyak berkaitan dengan pembentukan kolagen meskipun dasar sintesis kolagen bergantung pada usia (Phillips et al., 1994). Vitamin $C$ diperlukan untuk hidroksilasi prolin dan lisin menjadi hidroksiprolin, bahan penting dalam pembentukan kolagen. Kolagen merupakan senyawa protein yang mempengaruhi integritas struktur sel di semua jaringan ikat, seperti tulang rawan, matriks tulang, dentin gigi, membrane kapiler, kulit dan tendon (urat otot). Dengan demikian vitamin $\mathrm{C}$ berperan dalam penyembuhan luka, Vitamin $\mathrm{C}$ meningkatkan daya tahan terhadap infeksi, kemungkinan karena pemeliharaan terhadap membrane mukosa atau pengaruh terhadap fungsi kekebalan (Almatsier, 2009)

Sedangkan pada kelompok kontrol yang tidak mengkonsumsi jus jambu biji merah terdapat 90\% responden sembuh dalam batas waktu normal yaitu hari ke 7 sampai hari ke 10, dan $10 \%$ responden sembuh dalam waktu yang lama yaitu lebih dari 10 hari, 4 responden mengalami ruptur perineum derajad I dan 6 responden mengalami ruptur perineum derajad II, tidak ada yang mengalami penyembuhan luka lebih cepat $<7$ hari karena pada kelompok kontrol tidak mendapatkan tambahan asupan vitamin $\mathrm{C}$ dari jambu biji merah sehingga tidak terjadi sintesis kolagen.

\section{PENUTUP}

Penelitian ini telah menunjukkan bahwa konsumsi jus jambu biji merah berpengaruh terhadap penyembuhan luka perineum pada ibu postpartum, sehingga dapat diterapkan dalam perawatan pasca persalinan terutama untuk penyembuhan luka perineum. Buah Jambu biji mudah didapatkan dalam kehidupan sehari-hari dan dengan harga yang cukup terjangkau dan dengan cara pembuatan jus yang mudah. Pengetahuan tentang jus jambu biji merah bisa didapatkan melalui buku-buku maupun artikel ilmiah. Sehingga dapat memanfaatkan jambu biji merah sebagai produk makanan lain selain jus. Selain itu penerapan konsumsi jus jambu merah juga harus memperhatikan faktor-faktor lain yang dapat mempengaruhi waktu penyembuhan luka seperti obat-obatan pasca persalinan dan makanan yang dikonsumsi sehingga kolaborasi antara dua hal tersebut diharapkan dapat memberikan hasil penyembuhan luka yang optimal.

\section{DAFTAR PUSTAKA}

Almatsier,S. 2009. Prinsip Dasar Ilmu Gizi. Jakarta: Gramedia Pustaka Utama.

Baxter C.1990. The normal healing process. In: New Directions in Wound Healing. Wound care manual; February 1990. Princeton, NJ: E.R. Squlbb \& Sons, Inc

Asiyah, N. (2013). Perbedaan Kejadian Ruptur Perineum Pada Posisi Mengejan Antara Telentang Dan Kombinasi. Jurnal Ilmu Keperawatan dan Kebidanan, 4(2).

Destiati, L., \& Prabandari, F. (2011). Hubungan Antara Berat Badan Bayi Baru Lahir Dan Paritas Dengan Ruptur Perineum Pada Persalinan Spontan Di Rsia "Bunda Arif" Purwokerto Tahun 2010. Jurnal Bidan Prada, 2(02).

Mahsudi. 2004. Food supplement. Jakarta: PT gramedia

Meyta Winduka, AMG. 2011. Gizi. Jakarta : Wordpress

Manuaba, dkk. 2007.Pengantar Kuliah Obstetri. Jakarta: EGC 
Mitchell. 2009. Dasar Patologis Penyakit. Jakarta : EGC

Moya J. Morison, 2004. Manajemen Luka. Jakarta : EGC

Oswari E. 1993. Bedah dan perawatannya. Jakarta : Gramedia

Phillips, C. L., Combs, S. B., \& Pinnell, S. R. (1994). Effects of ascorbic acid on proliferation and collagen synthesis in relation to the donor age of human dermal fibroblasts. Journal of Investigative Dermatology, 103(2), 228-232.
Pratami, E. R., \& Kuswanti, I. (2015). Hubungan Paritas Dengan Derajat Ruptur Perineum Pada Ibu Bersalin Normal Di Puskesmas Tegalrejo Yogyakarta. Jurnal Kesehatan Samodra Ilmu, 6(1).

Prawirohradjo, 2006. Ilmu Bedah. Jakarta : EGC

Smeltzer, Suzanne C. 2001. Buku Ajar Keperawatan Medikal Bedah Vol 1. Jakarta : EGC 